\title{
PROGRESS WITH MONITORING AND ASSESSMENT IN THE WFD IMPLEMENTATION IN FIVE EUROPEAN RIVER BASINS: SIGNIFICANT DIFFERENCES BUT SIMILAR PROBLEMS
}

\author{
THEODOROS GIAKOUMIS and NIKOLAOS VOULVOULIS*
}

\author{
Centre for Environmental Policy, Imperial College London, London SW7 2AZ, UK \\ * Corresponding author: n.voulvoulis@imperial.ac.uk
}

\section{ABSTRACT}

The river basin approach of the Water Framework Directive (WFD) and the introduction of ecological status represent a shift in the assessment and management of freshwater systems from discipline-specific to more holistic, catchment-based principles. At the core of the WFD's approach are catchments as highly interconnected systems. Despite strict timetables, progress towards achieving the WFD objectives has been slow, with deterioration in some cases not being halted. In this paper, looking at evidence from five European basins (Adige, Anglian, Ebro, Evrotas and Sava) we identify some of the key implementation challenges faced by each catchment during the development and implementation of the 1st River Basin Management Plans (RBMPs) of 2009. Despite significant differences in socio-ecological conditions, geographic coverage and starting points in the implementation between these river basins, findings highlight some similar key issues. The lack of a common systemic understanding of each river basin and detailed monitoring data to capture pressure-status interactions in order to anticipate how the system will react to interventions; as well as compliance driven implementation efforts were underlying problems in all five study areas. While some improvements to address these problems can be seen in the 2nd River Basin Management Planning Cycle (2015-2016), our findings demonstrate that a more effective approach is to question the deviation of the whole implementation from the directive's systemic nature and therefore improve the adaptive, collaborative, participatory and interdisciplinary nature of the implementation efforts.

Keywords: catchment management; ecosystem services; systems thinking; water framework directive

\section{Introduction}

The river basin approach of the Water Framework Directive (WFD) and the introduction of ecological status represent a shift in the assessment of freshwater systems from discipline-specific to more holistic, catchment-based principles. The Directive offered a tailored approach to improving water quality by conceptualizing and managing catchments as highly interconnected systems. It sets specific procedural obligations for its implementation by Member States aiming at the coordinated and harmonized transposition of the Integrated River Basin Management paradigm as the process for delivering good ecological status. Its approach was characterized as innovative, ambitious and revolutionary, which accounts for the great expectations that came with the WFD, leading to it being considered as a potential template and basis for future environmental regulations (Josefsson 2012).

However, the monitoring and assessment of European waters under the WFD required a new mind-set and a new procedure, which most Member States found challenging to implement. Fifteen years after the Directive was introduced, and with many problems and delays in its implementation, progress towards achieving WFD objectives has been slow with deterioration in some cases not being halted (European Commission 2015a).

This article examines implementation practices in five European river basins during the 1st WFD management cycle (2009-2015) in order to identify some of the key challenges of monitoring and assessment. It investigates the deviation of practices at the catchment level from the WFD's aspirations in order to highlight important lessons that could help future implementation. Also by looking into early reports on the development of the 2015 River Basin Management Plans (RBMPs) for the 2nd planning cycle this article evaluates whether the Member States have learnt from the lessons of the 1 st cycle.

\section{Materials and Methods}

Based on data obtained from: EU directives, European Commission policy documents (Implementation Reports and various technical reports), scientific journals, grey literature, EU and national research projects and RBMPs, an extensive policy analysis was undertaken for this study. This work reviews how the procedures outlined in the WFD were interpreted and applied at the catchment scale by focusing on the monitoring and assessment of water body status as required by the Directive.

\section{The process of monitoring and assessment of water body status under the WFD}

River Basin Management (RBM) planning under the WFD begins with the competent authorities and all relevant parties defining the system of interest (river basin) and developing a robust understanding of its characteristics and conditions. The characterization of the river basin is a stepwise process that includes four main ele- 
ments; characterization of water bodies, typologies, reference conditions and pressure-impact analysis (Fig. 1). The WFD introduced multi-objective monitoring, consisting of three types: surveillance, operational and investigative, as specified in Annex V (European Communities 2003a). The process of assessing ecological status is based on several elements that aim to indicate the deviation of the system from its state under undisturbed/ reference conditions (Fig. 1). The resultant classification follows a one out-all out scheme at the level of the quality elements, meaning that a water body cannot be assigned a good ecological status if any element has a value that deviates moderately or significantly from those normally associated with undisturbed conditions (European Communities 2005).

\section{The selected basins}

The selected basins encompass a rich set of socio-ecological conditions and wide geographic coverage. These are: Ebro in Spain and Evrotas in Greece (both in the Mediterranean), Sava, (which is a continental and trans-boundary, shared between Slovenia, Croatia, Bosnia and Herzegovina and Serbia), Adige in Italy (an Alpine basin) and Anglian in the UK. Each case study has its own water management history and thus, any comparisons between them need to be based on a clear understanding of the characteristics and context of each case study. This article focuses solely on the implementa- tion of WFD monitoring and assessment requirements, and reviews progress in each catchment since the WFD was adopted. For this, the key characteristics of the preWFD water management regime at each catchment are summarized in Table 1.

\section{Common Implementation Challenges (1st cycle of RBMPs)}

Discrepancies in characterization, including the delineation of water bodies, typology and reference conditions, were identified to different degrees in all five river basins. In the Evrotas and Sava the reference conditions were not established in time while in the Ebro River Basin District (RBD) the reference conditions were reported to be incoherent (European Commission 2015a; European Commission 2015b; ISRBC 2013a). In Adige and Anglian RBDs, no biological information for the different types surface water was provided (European Commission 2012a; European Commission 2012b). Also, in the Ebro RBD a lack of coherence in the typology has affected the process of determining the status or setting environmental objectives for transitional and coastal water bodies (European Commission 2015b). Furthermore, in the Anglian RBD, Ebro RBD and Sava RBD, there has been a need to revise and improve the designation of heavily modified and artificial water bodies (Environ-

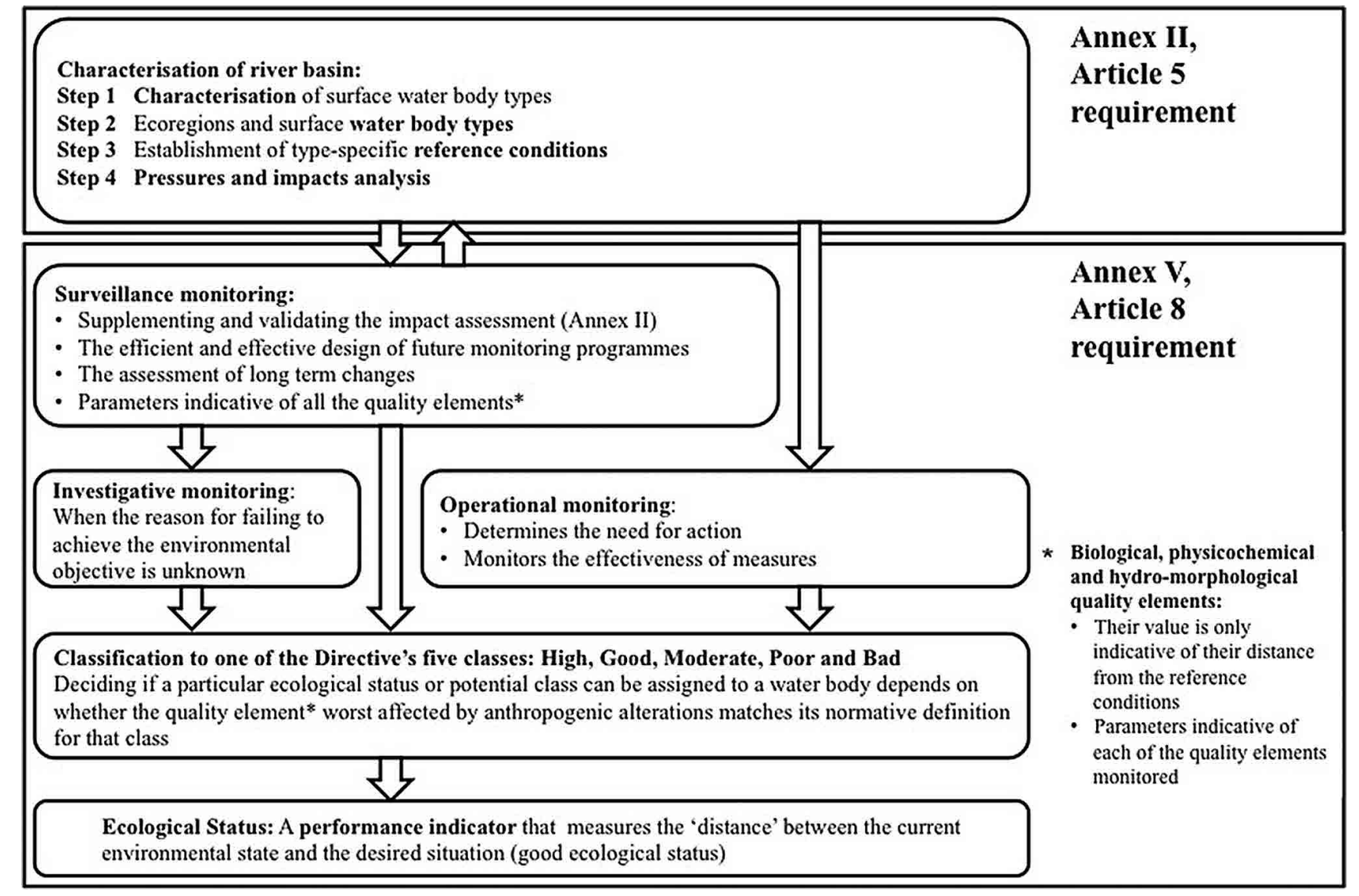

Fig. 1 The procedures for monitoring and assessing under the WFD. 
Table 1 The key characteristics of the pre-WFD water management regime in the selected basins.

\begin{tabular}{|c|c|c|}
\hline Basins & Structures and administrative arrangements & Monitoring infrastructure and assessment \\
\hline Adige (Italy) & $\begin{array}{l}\text { - The National Environmental Protection Agency established } \\
\text { in } 1994 \\
\text { - Water basin authorities (Goria and Lugaresi 2004) develop } \\
\text { and apply the River Basin Management Plan } \\
\text { - This plan includes four transitional plans: i) the transitional } \\
\text { plan for the restoration of hydraulic structures; ii) the transi- } \\
\text { tional plan for the hydro-geological Settlement, also contain- } \\
\text { ing the transitional plan for fluvial areas; iii) the special plan } \\
\text { for areas with high hydro-geological risks; iv) the transitional } \\
\text { plan for the control of eutrophication (Balzarolo et al. 2011). }\end{array}$ & $\begin{array}{l}\text { - Monitoring of programs was undertaken at the local } \\
\text { level, on a case-by-case basis. } \\
\text { - The range and extent of programs may vary but local } \\
\text { monitoring can be divided into: trend detection and gen- } \\
\text { eral quality characterization, assessment of the effects of } \\
\text { discharges and point pollution incidents (Lawson 2005). }\end{array}$ \\
\hline Anglian (UK) & $\begin{array}{l}\text { - Regional Water authorities established in } 1974 \text { were deter- } \\
\text { mined by the river basin areas (Medd and Marvin, 2007). } \\
\text { However, they were disassembled in } 1987 \text { in favor of the Na- } \\
\text { tional Rivers Authority, which kept the regional management } \\
\text { structure and geographical boundaries } \\
\text { - The Environmental Act in } 1995 \text { established the Environment } \\
\text { Agency. The new management regime was organized on } \\
\text { a regional basis being a combination of river basins and } \\
\text { administrative boundaries (Chave 2001). }\end{array}$ & $\begin{array}{l}\text { - Since 1970, General Quality Assessment consisted of } \\
\text { monthly spot monitoring of the chemical components, } \\
\text { dissolved oxygen, biochemical oxygen demand and } \\
\text { ammonical nitrogen, and the nutrients phosphate and } \\
\text { nitrogen, in stretches of water with a flow greater than } \\
1 \mathrm{~m}^{3} / \mathrm{s} \text {. } \\
\text { - Biological Monitoring Working Party scoring, has been } \\
\text { used since the } 1980 \mathrm{~s} \\
\text { - In } 1994 \text { the Fish Identification Scheme was implemented } \\
\text { - In } 1995 \text { the development of the Surface Water Abstrac- } \\
\text { tion Licence Procedure was developed. } \\
\text { - River Invertebrate Prediction and Classification System } \\
\text { (RIVPCS). } \\
\text { - The river habitat survey was developed in order to assess } \\
\text { the physical structure of rivers. }\end{array}$ \\
\hline Ebro (Spain) & $\begin{array}{l}\text { - The Ebro river basin has had a specific water agency for water } \\
\text { management since 1926, the Ebro Hydrographic Confedera- } \\
\text { tion, but with overlapping institutions and agents that make } \\
\text { the actual management more complex (Bielsa and Cazcarro } \\
\text { 2015). }\end{array}$ & $\begin{array}{l}\text { - Different types of monitoring networks } \\
\text { - Monitoring of the quality and quantity of ground water } \\
\text { but quite differently from that required by the WFD. } \\
\text { - Abstraction data were not accurate enough. } \\
\text { - Lack of biological data } \\
\text { - Heterogeneity of data sources and data. }\end{array}$ \\
\hline Evrotas (Greece) & $\begin{array}{l}\text { - Decisions concerning national water planning were taken } \\
\text { by different central governmental agencies, or at the local } \\
\text { level, by the responsible municipal authorities, while local/ } \\
\text { regional social actors were totally excluded (Demetropoulou } \\
\text { et al. 2010). }\end{array}$ & $\begin{array}{l}\text { - Poor technical infrastructure. } \\
\text { - Lack of a unified network in the Country, various } \\
\text { networks existed managed by various agencies and for } \\
\text { various purposes. } \\
\text { - Inadequate and unreliable field data (Alexopoulou et al. } \\
\text { 2005). }\end{array}$ \\
\hline $\begin{array}{l}\text { Sava (Slovenia, } \\
\text { Croatia, Bosnia } \\
\text { and Herzegovina } \\
\text { and Serbia) }\end{array}$ & $\begin{array}{l}\text { - The decay of the former Yugoslavia (1990s) challenged water } \\
\text { management, because the Sava river from the being the larg- } \\
\text { est river in Yugoslavia became an international river flowing } \\
\text { through several countries (Komatina and Groselj 2014) } \\
\text { - Republic level authorities in Slovenia and Croatia (Čolak- } \\
\text { hodžić et al. 2014). } \\
\text { - In Serbia Public Water Management Company "Serbia Waters" } \\
\text { was created in } 1996 \text { to implement the water management } \\
\text { activities (UN 2004). } \\
\text { - Bosnia and Herzegovina, is a relatively new post-war democ- } \\
\text { racy, and thus new structures had to be established. }\end{array}$ & $\begin{array}{l}\text { - Monitoring activities differed in the different countries } \\
\text { and was generally limited to certain river sections, or to } \\
\text { particular variables, and datasets that are not entirely } \\
\text { comparable. }\end{array}$ \\
\hline
\end{tabular}

ment Agency 2009; European Commission 2012b; ISRBC 2013b; Environment Agency 2015).

The pressures and impacts analysis and its implications for the identification of the significant pressures that need to be monitored, seem to be the greatest issue in all basins. In the Ebro RBD there seems to be a mismatch between the pressures in the catchment and the ones' reported. Although, water quantity has been a significant problem, there are relatively few water bodies identified as being significantly affected by water abstraction. This could be attributed to the fact that Spain reports only the results of a qualitative pressure and impact assessment to the Water Information System for Europe, which is not accurate in case of water abstraction (European Commission 2015b). Similarly, and despite the large number of dams and river infrastructure existing at Ebro, relatively few water bodies $(<20 \%)$ are reported to be significantly affected by the results of water flow regulations and hydro-morphological alterations (European Commission 2015b). Although the Directive requires the pressure and impacts analysis to be a continuous process validated and supplemented by monitoring, generally in Spanish catchments the final and complete assessment of pressures and impacts was wrongly seen as a one-off exercise, which was due only in 2005 as part of the preparation of the 1st RBMPs. 
Current assessment schemes mainly focus on more traditional pressures (e.g. eutrophication, organic pollution) (Hering et al. 2010) neglecting other pressures that have more recently come into focus. One of which includes the implications of climate change in water management. As an example, there are issues identified with regards to the effect of climate change associated with the release of chemical pollutants from snow and glacier melting, an occurrence that has not yet been fully investigated in the case of the Adige basin (Chiogna et al. 2016). Similarly, the Ebro RBMPs states that, in the absence of evaluations of the climate scenario prepared by the Ministry of the Environment, a rigid percentage (5\%) in the global reduction of natural contributions must be applied, but this plan ignores current research findings for which that reduction for 2050 is expected to be in the range 15\%-35\% (Bielsa and Cazcarro 2015). This raises another question from a managers' perspective with regards to the reliability of the thresholds of significance used for the pressure inventories. This is apparent in the cases of the Evrotas basin and Sava RBD where the criteria for identification of significant pressures haven't been catchment specific (Central Water Agency 2006; ISRBC 2013a). Although this practice provides an initial starting point and baseline for the pressure and impact analysis, using one set of thresholds across Europe is not ideal since this fails to recognize the particular characteristics of the water body and its vulnerability to pressures (European Communities 2003b). The Anglian RBD is a better example of the application of the pressure assessment. A preliminary analysis of the pressures and impacts revealed some issues including the identification of the effects of hydro-morphological pressures on the ecological status, the limitations of the traditional General Quality Assessment to represent effect data as well as the challenges in understanding the relationship of the link drivers to the pressures (DEFRA 2005).

The problem of identifying significant pressures affects the classification of statuses and this has been another source of error identified in all the basins. For example, although the assessment of pressure effects in the Ebro RBD has identified $77 \%$ of the water bodies ( 635 water bodies) as not affected, however, when compared to the number of good status water bodies in 2009 (226 water bodies) the number of good status surface water bodies is much less than the number of water bodies not affected (European Commission 2015b). Another illuminating example comes from the Croatian part of the Sava RBD. Although, Biological Quality Elements (BQEs) in operational monitoring were chosen in relation to existing pressures, there is no clear evidence to show which BQEs were selected to monitor the significant pressures. The RBMP of Croatia also reports that operational monitoring was only carried out in relation to point source pressures, not diffuse sources.

Another important challenge in implementing operational monitoring and delivering reliable classifications is the lack of well-established methods of assessment for all BQEs. For Adige, Ebro, Evrotas and Sava the methods for assessing ecological status were not developed for all BQEs specified in the WFD and as a result not all BQEs were monitored. Although this could be a one-off problem, there are cases where this has compromised the selection of the most appropriate indicators of significant pressures. In the Evrotas basin the classification of rivers as far as BQSs is concerned was based on monitoring of benthic invertebrates and fish (fish were not included in the Evrotas tributaries) since for the macro algae and phytobenthos it was not feasible to determine the class boundary limits (Nikolaidis et al. 2009). In the Anglian $\mathrm{RBD}$, despite having one of the most intensive monitoring networks, not all of the relevant quality elements are monitored. Although all relevant BQEs were used in operational monitoring, not all supporting elements were. For example, there was no monitoring of river continuity, tidal regime in coastal waters or fish in lakes (European Commission 2012b). In addition, 54\% of water bodies were monitored for at least one biological element, scoring the lowest among the other catchments within England and Wales (Collins et al. 2012). More severe gaps in elements monitored are present in the case of the Sava trans-boundary catchment, potentially due to differing levels of the WFD implementation among the countries involved. For example, while in Slovenia operational monitoring covers most of the relevant quality elements, in Croatia the preliminary assessment of the ecological status was made using only physico-chemical and hydro-morphological quality elements (European Commission 2015c). In Serbia the monitoring and assessment of the ecological and chemical status for the Sava RBMP is not fully compliant with the requirements of WFD, while in Bosnia and Herzegovina they were not implemented (ISRBC 2013a).

\section{Lessons from the 1st RBM Planning Cycle and Signs of Progress}

The problems in implementing the procedures outlined in the RBM planning has knock on effects on the subsequent steps and reduces the reliability of their outputs. In Anglian, the 2nd cycle brought improvements, making the characterization of surface water systems more ecologically relevant by changing water body boundaries and designating coastal and transitional types. In Ebro there was no update of the designation process of heavily modified water bodies and the definition of good ecological potential, while in Sava RBD there was a lack of harmonization of trans-boundary water bodies. However, in all three case studies there was good progress with the definition of reference conditions for certain biological quality elements. (Environment Agency 2015; European Commission 2015d; ISRBC 2016).

The assessment of pressures and impacts is an on-going process within RBM planning, which should be kept 
up to date to enable timely, appropriate and effective water management (European Communities 2003b). In Ebro however, there is still no review of the legislation for explicitly incorporating the identification of water bodies at risk identified by the pressures and impacts analysis and there are no clear criteria for defining significant adverse effects (European Commission 2015d). In Sava, the risk assessment was implemented in terms of ongoing pressures (organic, hazardous substances and nutrient pollution and hydro-morphological alteration) and their future development but the risk to over $26 \%$ of Sava water bodies and $50 \%$ of its tributaries is unknown (ISRBC 2016). In Anglian, the risk assessments have been improved and the outputs were utilized in the design of the monitoring networks (Environment Agency 2015).

The validation of the pressure and impacts analysis using surveillance-monitoring data is especially important in the context of multiple pressure interactions. As freshwater systems are influenced by pressures whose effects are relevant at multiple spatial and temporal scales, the thresholds of significance for example of a certain pollutant may change based on the specific characteristics of the catchment. For example, even low levels of contamination may become relevant for the ecosystem when it is subject to additional hydrological stressors. The identification of 'significant' pressures may still prove difficult, if the combined effects of non-significant pressures are neglected. Complex synergistic or antagonistic interactions between multiple pressures are very common (Piggott et al. 2015) and therefore one of the largest sources of uncertainty when predicting ecological change. A recent study (Chiogna et al. 2016) in the Alpine catchment of Adige showed how unpredictable the effects of such pressure interactions can be. According to the classification data collected by the relevant authorities, the highest quality values were recorded in the upstream regions compared to those downstream where the ecological status deteriorated. Such a north-south gradient in ecological status recorded at the monitoring points along the Adige seems to contradict the evidence that hydropeaking generally has a negative effect on the ecosystem as the data demonstrate that the worst ecological status is recorded where the effects of hydropeaking are negligible (Chiogna et al. 2016).

Operational monitoring should focus on parameters indicative of quality elements most sensitive to the pressures affecting the status of a water body (European Communities 2003a). Apart from the pressure and impact analysis, which identifies significant pressures, the reliability of the overall classification of ecological status, depends on the existence of appropriate methods for assessing the relevant BQEs. In the Anglian RBD a new monitoring network was introduced in 2013 and 2014 with a better coverage of BQEs. The methods for assessing surface and ground water status were improved by including: new standards for additional chemical substances, updated standards for existing physico-chemi- cal elements and improvements in biological assessment tools, although fish in lakes are still not being assessed (Environment Agency 2015). In Ebro, there has also been some progress with new protocols and indicators added to monitoring (European Commission 2015d). However, there are still gaps in monitoring coastal and transitional waters and in the assessment of ground water quantitative status. The status of $33 \%$ of lake and river water bodies has still not been assessed. Regarding, the Sava RBD, Slovenia and Croatia have now established monitoring programs in line with the principles of the WFD, while the other Sava countries are still in the development phase (ISRBC 2016).

\section{Discussion and Conclusion}

This paper aimed to provide insights into the complexities and challenges of the monitoring and assessment required by the WFD by presenting examples of implementation problems in five European river basins; Adige, Anglian, Ebro, Evrotas and Sava. Despite their differences, the main implementation challenges are similar in all basins: the lack of a common systemic understanding of each river basin; absence of detailed monitoring data on pressure-status interactions in order to anticipate how the system will react to interventions and overall compliance driven implementation efforts.

Although this has been attributed to the resistance and unwillingness to change from usual practices (Hering et al. 2010), misunderstandings of some of the Directive's innovations such as the role of ecological status as a performance indicator of the health of a system have also potentially contributed (Voulvoulis et al. 2017). Early signs of progress seen in the 2nd RBM planning cycle were mainly procedural, with no clear evidence that these misunderstandings have been resolved.

Member States continue to focus implementation efforts on how to meet the Directive's procedural requirements without appreciating, if not, understanding the Directive's new approach. Compliance driven implementation for example in the UK, was criticized as "implementation turned into a "tick list" of compliance, for small water bodies, against some 50 sets of standards" (Everard 2012). Assessment and management focus on the parts rather than overall ecosystem health, and without addressing their interactions, in contrast to the aspirations of the inherently systematic WFD. The WFD's ecosystems approach for the assessment of surface water system health and the introduction of ecological status represents a shift from disciple specific approaches towards holistic resource performance assessments, which requires an interdisciplinary mind-set. Traditional silo-based management rooted in disciplinary thinking often provides an incomplete representation of the entire environmental system (Jones et al. 2011). In principle, the Directive encourages research, 
involving social and natural scientists and engineers, on understanding changes in water systems and their interactions with human activities (Hodgson and Smith 2007). Therefore by integrating multiple perspectives in the decision-making process the WFD seeks a robust understanding of the issues and interactions within the catchment (Collins et al. 2007).

The use of "all available" knowledge was intended to encourage public participation in the WFD and yet, the knowledge of local people is not generally used by most scientists and authorities (Valinia et al. 2012). River basin characterizations, including the risk assessments in the case studies, focus only on technical considerations, which are often unclear to the public, water users and stakeholders. Instead, stakeholder views should be included in the conceptual models that should be examined by other stakeholders while technical experts should aim to facilitate the needs and views of these participants (Hart et al. 2006). The fact that the concept of "desired state" by definition requires multiple perspectives, ecosystem health does not equate simply either to biotic integrity or to habitat quality and thus defining health cannot be primarily rooted in one scientific discipline or in one particular aspect (e.g. a single group of taxa) (Fairweather 1999). The way good status has been understood and approached neglects the interdisciplinary nature of ecosystem health if engaging with stakeholders by means of a catchment participatory process does not take place. Identifying community aspirations for each water body is critical. The Directive requires involving the public, water users and stakeholders at an early stage (Article 14 of the WFD) and through all management steps, including the setting of reference condition as is stressed in Guidance Document No. 8 (European Communities 2003c). As the guidance documents are not legally binding for the Member States, public participation has been heavily dependent on the political will of the relevant authorities.

Making the WFD's systemic integration of multiple perspectives operational has a long way to go, with some evidence of a transition towards an adoption of the ecosystems approach by integrating Ecosystem Services in the implementation process (Voulvoulis et al. 2017). Even though Ecosystem Services are not explicit in the wording of the WFD, there is a clear connection between the Directive and their delivery (Vlachopoulou et al. 2014). Investigating further the relationship between environmental 'state' and 'effects' on the quality elements monitored under the WFD and how they link to the provision of Ecosystem Services could enable greater involvement by the stakeholders in defining the desired state of the freshwater system. Adopting the Ecosystem Services language; a participatory approach for the assessment under the WFD could be facilitated, by translating how changes in water quality status reflects changes in those services and goods they value. The stakeholders could provide a more robust definition of good ecological status based on what they value. Using Ecosystem Services as the proxy of those natural elements of water systems that are ultimately valued by our society, its integration in decision making by explicitly identifying the interdependencies of how human activities within the catchment influence their provision (Asah et al. 2014) could support the implementation of the monitoring and assessment under the WFD.

\section{Acknowledgments}

This work was supported by the European Communities 7th Framework Programme Funding under Grant agreement no. 603629-ENV-2013-6.2.1-GLOBAQUA.

\section{REFERENCES}

Alexopoulou A, Makropoulos C, Voulvoulis N (2005) Water framework directive: Implementation in Greece. Univ Aegean, pp A56-A65.

Asah ST, Guerry AD, Blahna DJ, Lawler JJ (2014) Perception, acquisition and use of ecosystem services: Human behavior, and ecosystem management and policy implications. Ecosyst Serv 10: $180-186$.

Balzarolo D, Lazzara P, Colonna P, Becciu G, Rana G (2011) The implementation of the Water Framework Directive in Italy. Options Mediterrannées, 98

Bielsa J, Cazcarro I (2015) Implementing Integrated Water Resources Management in the Ebro River Basin: From Theory to Facts. Sustainability 7: 441-464.

Central Water Agency (2006) Report on the pressures and qualitative characteristics of water bodies in the water districts of Greece and a methodological approach for further analysis.

Chave P (2001) The EU Water Framework Directive, Water Framework Directive Series. IWA Publishing.

Chiogna G, Majone B, Cano Paoli K, Diamantini E, Stella E, Mallucci S, Lencioni V, Zandonai F, Bellin A (2016) A review of hydrological and chemical stressors in the Adige catchment and its ecological status. Sci Total Environ 540: 429-443.

Čolakhodžić A, Filipović M, Kovandžić J, Stec S (2014) The Sava River Basin: Transitioning to peace in the former Yugoslavia. In: Weinthal E, Troell J, Nakayama M (eds) Water and Post-Conflict Peacebuilding. Earthscan, London.

Collins K, Blackmore C, Morris D, Watson D (2007) A systemic approach to managing multiple perspectives and stakeholding in water catchments: some findings from three UK case studies. Environ Sci Policy 10: 564-574.

Collins A, Ohandja DG, Hoare D, Voulvoulis N (2012) Implementing the Water Framework Directive: a transition from established monitoring networks in England and Wales. Environ Sci Policy 17: 49-61.

DEFRA (2005) Water Framework Directive Summary report of the characterisation, impacts and economics analyses required by Article 5. Anglian River Basin District.

Demetropoulou L, Nikolaidis N, Papadoulakis V, Tsakiris K, Koussouris T, Kalogerakis N, Koukaras K, Chatzinikolaou A, Theodoropoulos K (2010) Water Framework Directive Implementation in Greece: Introducing Participation in Water Governance - the Case of the Evrotas River Basin Management Plan 349: 336-349. 
Environment Agency (2009) Water for life and livelihoods, River Basin Management Plan Anglian River Basin District, Annex B: Water body status objectives.

Environment Agency (2015) Water for life and livelihoods, Part 1: Anglian river basin district River basin management plan.

European Commission (2012a) Commission Staff Working Document, Report on the implementation of the Water Framework Directive River Basin Management Plans, Member State: Italy, Accompanying the document: "Report from the European Commission to the European Parliament and the Council, on the implementation of the Water Framework Directive (2000/60/EC) River Basin Management Plans", SWD (2012) 379 Final

European Commission (2012b) Commission Staff Working Document, Report on the implementation of the Water Framework Directive River Basin Management Plans, Member State: United Kingdom, Accompanying the document: "Report from the European Commission to the European Parliament and the Council, on the implementation of the Water Framework Directive (2000/60/EC) River Basin Management Plans", SWD (2012) 379 Final.

European Commission (2015a) Commission Staff Working Document, Report on the progress in implementation of the Water Framework Directive Programmes of Measures. Accompanying the document: Communication from the Commission to the European Parliament and the Council. The Water Framework Directive and the Floods Directive: Actions towards the 'good status' of EU water and to reduce flood risks. COM (2015) 120 Final.

European Commission (2015b) Commission Staff Working Document, Report on the implementation of the Water Framework Directive River Basin Management Plans, Member State: Spain, Accompanying the document: "Communication from the European Commission to the European Parliament and the Council, The Water Framework Directive and the Floods Directive: Actions towards the 'good status' of EU water and to reduce flood risks” SWD (2015) 56 Final.

European Commission (2015c) Commission Staff Working Document, Report on the implementation of the Water Framework Directive River Basin Management Plans, Member State: Croatia, Accompanying the document: "Communication from the European Commission to the European Parliament and the Council, The Water Framework Directive and the Floods Directive: Actions towards the 'good status' of EU water and to reduce flood risks" SWD (2015) 53 Final.

European Commission (2015d) Screening Assessment of Draft Second Cycle River Basin Management Plans.

European Communities (2003a) Common implementation strategy for the Water Framework Directive (2000/60/EC). Guidance Document No. 7, Rivers and Lakes - Monitoring under the Water Framework Directive.

European Communities (2003b) Common Implementation Strategy for the Water Framework Directive (2000/60/EC), Guidance Document No. 3, Analysis of Pressures and Impacts.

European Communities (2003c) Common Implementation Strategy for the Water Framework Directive (2000/60/EC), Guidance Document No. 8, Public Participation in Relation to the Water Framework Directive.

European Communities (2005) Common Implementation Strategy for the Water Framework Directive (2000/60/EC), Guidance
Document No. 13, Overall Approach to the Classification of Ecological Status and Ecological Potential.

Everard M (2012) Beating the bean counters. The Environmentalist. Fairweather PG (1999) State of environment indicators of "river health": Exploring the metaphor. Freshw Biol 41: 211-220.

Goria A, Lugaresi N (2004) The Evolution of the Water Regime in Italy. In: Kissling-Näf I, Kuks S (eds) The Evolution of National Water Regimes in Europe: Transitions in Water Rights and Water Policies. Springer Netherlands, Dordrecht, pp 265-291.

Hart BT, Burgman M, Grace M, Pollino C, Webb JA (2006) RiskBased Approaches to Managing Contaminants in Catchments, pp 66-73.

Hering D, Borja A, Carstensen J, Carvalho L, Elliott M, Feld CK, Heiskanen AS, Johnson RK, Moe J, Pont D, Solheim Al, de Bund W van (2010) The European Water Framework Directive at the age of 10: a critical review of the achievements with recommendations for the future. Sci Total Environ 408: 4007-4019.

Hodgson SM, Smith JWN (2007) Building a research agenda on water policy: an exploration of the Water Framework Directive as an interdisciplinary problem. Interdisciplinary Sci Reviews 32(3): 187-202.

ISRBC (2013) Sava River Basin Management Plan.

ISRBC (2013b) Sava River Basin Management Plan. Background paper No.1 Surface water bodies in the Sava River Basin.

ISRBC (2016) 2nd Sava River Basin Analysis Report.

Jones NA, Ross H, Lynam T, Perez P, Leitch A (2011) Mental Model an Interdisciplinary Synthesis of Theory and Methods. Ecol Soc 16: 46-46.

Josefsson H (2012) Achieving Ecological Objectives. Laws 1: 39-63.

Komatina D, Groselj S (2014) Transboundary Water Cooperation for Sustainable Development of the Sava River Basin. In: Milačič R, Ščančar J, Paunović M (Eds) The Sava River, The Handbook of Environmental Chemistry. Springer Berlin Heidelberg.

Lawson J (2005) River Basin Management: Progress Towards Implementation of the European Water Framework Directive, Balkema-proceedings and monographs in engineering, water, and earth sciences. Taylor and Francis.

Medd W, Marvin S (2007) Strategic Intermediation : Between Regional Strategy and Local Practice. Sustain Dev 15: 318-327.

Nikolaidis N, Skoulikidis N, Papadoulakis V, Tsakiris K, Kalogerakis N (2009) Management Plans Pilot Rural Basin of Evrotas River, Technical Report 134 p. Edition: Nikolaidis N, Kalogerakis N, Skoulikidis N, Tsakiris K, 2005-2009. Environmental Friendly Technologies For Rural Development, Progam: LifeEnvironment, LIFE05ENV/Gr/000245 EE (EnviFriendly).

Piggott JJ, Townsend CR, Matthaei CD (2015) Reconceptualizing synergism and antagonism among multiple stressors. Ecol Evol 5: 1538-1547.

UN (2004) Freshwater Country Profile Serbia and Montenegro.

Valinia S, Hansen HP, Futter MN, Bishop K, Sriskandarajah N, Fölster J (2012) Problems with the reconciliation of good ecological status and public participation in the Water Framework Directive. Sci Total Environ 433: 482-490.

Vlachopoulou M, Coughlin D, Forrow D, Kirk S, Logan P, Voulvoulis N (2014) The potential of using the Ecosystem Approach in the implementation of the EU Water Framework Directive. Sci Total Environ 470-471: 684-694.

Voulvoulis N, Arpon KD, Giakoumis T (2017) The EU Water Framework Directive: From great expectations to problems with implementation. Sci Total Environ 575: 358-366. 